\title{
Identyfikacja i możliwość przystosowania łupków powęglowych z pirytem do stosowania w budownictwie drogowym
}

\author{
Andrzej Duszyński ${ }^{1}$, Wiktor Jasiński ${ }^{1}$, Lukasz Jórdeczka ${ }^{1}$, Aneta Pryga-Szulc ${ }^{1}$
}

\begin{abstract}
Identification and adaptation of coaly shales with pyrite for use in road construction. Prz. Geol., 68: 716-721; doi: 10.7306/2020.30
A b s t r a c t. Coaly shale is a full-fledged aggregate for road construction, which can be obtained through proper control and processing, meeting the performance characteristics for the application in the construction of embankments. In Poland, from current production and resources at landfills, coaly shale with a pyrite content above 1\% is a great potential for road construction. It requires adaptation, including on eliminating the possibility of bacteria decomposing this pyrite or its neutralization using limestone materials. At the same time, taking into account the weaknesses of coaly shale landfills (in terms of self-ignition and decomposition), the type of coaly shale and pyrite raw material can be identified as ways of using aggregates from these raw materials for the construction of embankments in the appropriate construction technology.
\end{abstract}

Keywords: coaly shale, pyrite, aggregate, material adaptation, embankment, built-way

Odpady wytworzone podczas wydobywania węgla kamiennego w 2016 r. wyniosły 32,7 mln Mg (Bochenek, 2017). Wyższy Urząd Górniczy (WUG) w sprawozdaniu z działalności urzędów górniczych w roku 2019 wskazuje, że w 2018 r. nadzorowane zakłady górnicze wytworzyły 66,2 mln t odpadów wydobywczych (Miklis, 2019). Szacowane ilości odpadów w górnictwie surowców energetycznych z węgla kamiennego na rok 2020 wyniosą $30,2 \mathrm{mln} \mathrm{Mg}$ (Szpadt, 2010), natomiast na rok 2025 - 29,6 mln Mg (Miklis, 2019; http://geoportal.pgi.gov.pl/odpady/wytwarzanie/prognozy).

Stawka opłat za składowanie odpadów z wydobywania kopalin innych niż rudy metali na składowisku w $2016 \mathrm{r}$. wyniosła 12,67 zł/Mg (Rozporządzenie, 2017). Na rok 2020 daje to kwote $30,2 \times 12,67=383 \mathrm{mln}$ zł w przypadku pełnego składowania tych odpadów.

Jak wynika z kontroli przeprowadzonej przez Najwyższą Izbę Kontroli (NIK) (Miklis, 2019) składowiska odpadów powydobywczych nadal pozostają nierozwiązanym problemem, ponieważ hałdy szpecą krajobraz i trwale wyłączają z użytkowania teren, na którym są posadowione. Przede wszystkim jednak narażają środowisko i ludzi mieszkających w ich pobliżu na zagrożenia wynikające z ich obecności (odcieki z hałd, zapylenie, pożary).

Jednocześnie kontrola NIK (Miklis, 2019) wykazała, że stosowane metody odzyskiwania odpadów powydobywczych nie gwarantują skutecznej ochrony przed wymienionymi zagrożeniami. W dodatku tylko $2,2 \%$ odpadów pogórniczych jest zagospodarowywane w sposób inny niż składowanie. Sposobem wykorzystania takich odpadów jest produkcja kruszyw dla budownictwa. Ze względu na ich właściwości fizykochemiczne zainteresowanie wykorzystaniem tych odpadów jest niestety znikome.

Istnieje wiele powodów takiego stanu:

- brak prawidłowej identyfikacji właściwości technicznych,

- niejednorodność składników w dostawie,
- przeobrażenia (wietrzenie) łupka powęglowego w wyniku działania czynników fizycznych i chemicznych,

- przenoszenie niekorzystnych zdarzeń związanych ze zwałowiskami na zastosowanie $\mathrm{w}$ budownictwie drogowym.

Przedmiot artykułu stanowią łupki powęglowe zaliczane do słabych i rozpadowych surowców skalnych. Szczególną uwage poświęcono tym, które zawierają dużą ilość pirytu (w przeliczeniu na siarkę pirytową powyżej 1\%). Stan zagospodarowania łupków powęglowych jest niewielki, a już szczególnie przy takiej zawartości pirytu. Celem artykułu jest wskazanie na możliwość pełnego wykorzystania łupków powęglowych w drogownictwie do budowy nasypów. Wobec braku normy na kruszywa z łupka powęglowego podstawą jego zastosowania w budownictwie dro-gowym jest Krajowa Ocena Techniczna Instytutu Badawczego Dróg i Mostów (KOT IBDiM). W tekście przedstawiono niektóre elementy dotyczące identyfikacji łupka powęglowego i jego wbudowania w nasyp. Szczegółowo poruszono te związane ze sposobami przystosowania surowca pod względem unieszkodliwiania pirytu oraz ze metodami wbudowania w nasyp łupka powęglowego zawierającego duże ilości pirytu. W badaniach wskazano na konieczność uwzględnienia faktu, że kruszywa z łupka powęglowego należą do kruszyw słabych i jednocześnie określono sposób projektowania szczelnych mieszanek o ciągłym uziarnieniu. Mieszanki te są przydatne do budowy warstw nasypu, ale również na okładziny nasypów z warstwami o dużej zawartości pirytu.

\section{ZWALOWISKA ODPADÓW POWĘGLOWYCH: SKLADNIKI I PROCESY}

Głównym składnikiem petrograficznym hałd łupków powęglowych są skały osadowe występujące w postaci luźnej lub zwięzłej, takie jak: iłowce, mułowce, łupki

\footnotetext{
${ }^{1}$ Instytut Badawczy Dróg i Mostów, Filia Wrocław, 55-140 Żmigród; aduszynski@ibdim.edu.pl; wjasinski@ibdim.edu.pl; 1jordeczka@ibdim.edu.pl; apryga@ibdim.edu.pl
} 
węglowe, piaskowce i żwirowce, piaski, sporadycznie zlepieńce, domieszki mineralne, głównie w postaci pirytu i syderytu, oraz pyły i pozostałości węgla (Sokół, Tabor, 1996; Machniak, Kozioł, 2014; Kozioł i in., 2015; Klojzy-Karczmarczyk i in., 2016). Procentowy udział tych składników jest zróżnicowany i zależy od rodzaju skał w miejscu wydobycia węgla (Duszyński i in., 2018).

Przeobrażenia składników w wyniku działania czynników zewnętrznych dotyczą przede wszystkim iłowców i mułowców, które pod wpływem zmieniających się warunków termiczno-wilgotnościowym ulegają szybko postępującym procesom wietrzeniowym (Sokół, Tabor, 1996). W wyniku rozpadu tych składników wzrasta ilość ziarn drobnych. Przemiany te w zasadniczy sposób wpływają na właściwości fizyczne i chemiczne lupka powęglowego (Duszyński i in., 2018).

Procesy wietrzeniowe zachodzące na zwałowiskach odpadów powęglowych w wyniku czynników fizycznych i chemicznych moga prowadzić do następujących przeobrażeń łupka powęglowego (Duszyński i in., 2018):

- rozpadu z pęcznieniem - skały ilaste, iłowce, łupki ilaste,

- rozpadu z lasowaniem bez pęcznienia - mułowce, łupki węglowe warstwowe ze skała płonną lub ze spoiwem ilastym lub węglanowym,

- rozmywalności (w stopniu zależnym od uporządkowania struktury minerałów ilastych),

- rozpadu z rozluźnianiem struktury ziarnistej - piaskowce,

- palności - przy zawartości węgla powyżej 30\%,

- utleniania - piryt, syderyt,

- agregacji ziarn drobnych lub ich klinowanie, w zależności od warunków i produktów przemian.

\section{Piryt}

Piryt jest znaczącym wskaźnikiem różnicującym łupki powęglowe pod względem zawartości siarki (Klojzy-Karczmarczyk i in., 2016), która może wynosić od 0,1 do ok. 5,0\%. Siarka występuje w węglach krajowych zarówno w związkach organicznych, jak i nieorganicznych (Blaschke i in., 2018; Duszyński i in., 2018).

Siarka nieorganiczna występuje w postaci pirytu $\left(\mathrm{FeS}_{2}\right)$, markasytu $\left(\mathrm{FeS}_{2}\right)$, rzadziej pirotynu (FeS), a także w postaci siarczanów (gipsu, epsomitu, jarosytu, melanterytu). Głównym nośnikiem siarki w węglach jest piryt. Siarczanów jest niewiele i są one produktami rozkładu pirytu. W węglach czasami może się znajdować siarka elementarna, ale są to bardzo rzadkie przypadki. Siarka nieorganiczna (głównie piryt) może wypełniać komórki mikroskładników węgla, np. w postaci cienkich naskorupień lub warstewki występującej na płaszczyznach spękań, wpryśnięć, soczewek i gniazd o wymiarach od kilku mikronów do kilku lub kilkunastu centymetrów, a także samodzielnych ziaren i kryształów różnej wielkości (Blaschke $\mathrm{i}$ in., 2018).

W polskich węglach zawartość siarki organicznej rzadko przekracza $0,6 \%$. Natomiast węgle występujące w wschodniej części Górnośląskiego Zagłębia Węglowego (GZW) charakteryzują się stosunkowo dużą zawartością siarki pirytowej. Przy zawartości siarki powyżej 0,8\% najczęściej, lub zawsze, będzie to piryt (Blaschke i in., 2018).

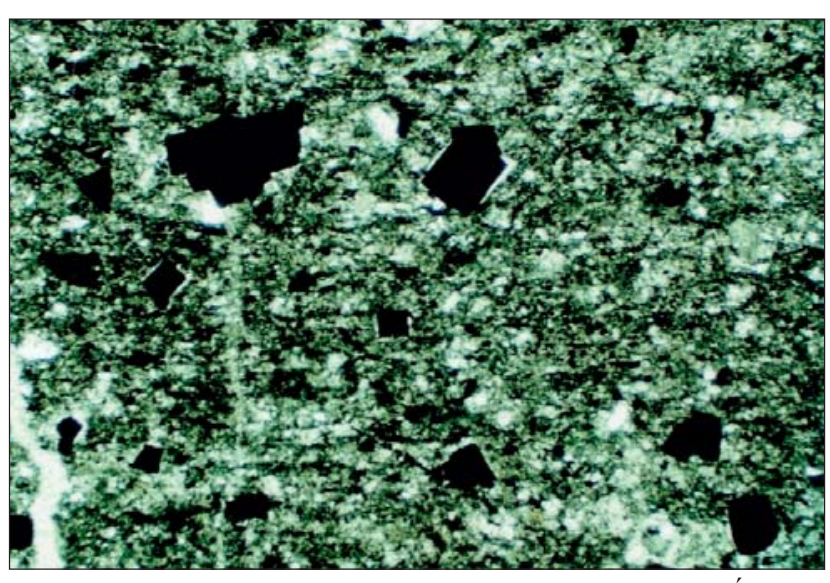

Ryc. 1. Euhedralne ziarna pirytu (czarne) w mułowcu. Światło przechodzące bez analizatora, pow. $400 \times$

Fig. 1. Euhedral pyrite grains (black) in mudstone. Transmitting light without analyzer, magnification $\times 400$

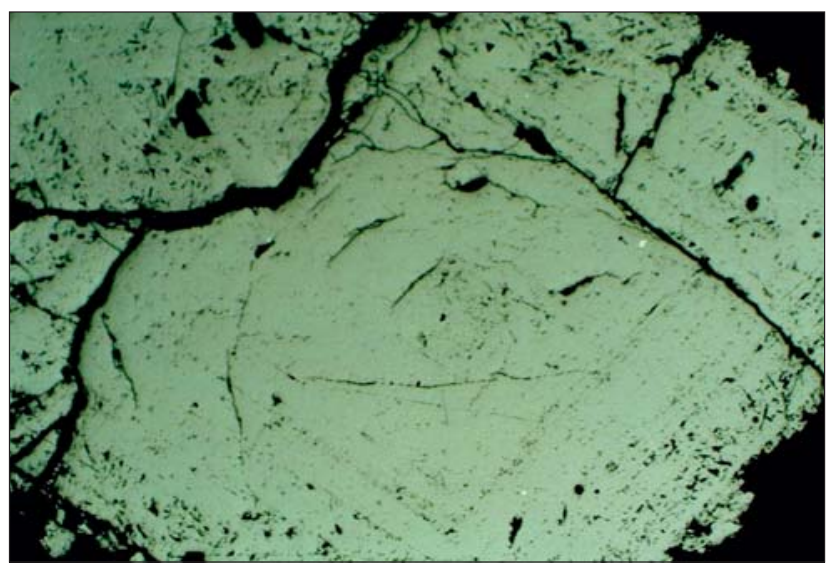

Ryc. 2. Budowa pasowa w przykładowym ziarnie pirytu w skale krzemionkowej. Światło odbite bez analizatora, pow. $40 \times$

Fig. 2. Zonal structure in an example of pyrite grain in silica rock. Reflected light without analyzer, magnification $\times 40$

Przykładowe ziarna pirytu w mułowcu (ryc. 1) oraz w skale krzemionkowej (ryc. 2) przedstawiono poniżej.

\section{WYKORZYSTANIE LUPKA POWĘGLOWEGO Z PIRYTEM DO BUDOWY NASYPÓW}

Łupek powęglowy jako surowiec do produkcji kruszywa może pochodzić:

- ze składowisk wewnątrzzakładowych z bezpośredniej produkcji węgla,

- ze składowisk zdeponowanych odpadów powęglowych,

- ze zwałowisk (hałd),

- ze składowisk po odzysku węgla ze zdeponowanych odpadów powęglowych.

Surowiec odpadowy łupka powęglowego może być zastosowany do budowy nasypów pod warunkiem spełnienia wymaganych właściwości użytkowych. Właściwości użytkowe określono $\mathrm{w}$ dokumencie odniesienia, jakim jest obecnie Aprobata Techniczna lub Krajowa Ocena Techniczna (KOT), jeśli definiuje takie zasadnicze charakterystyki jak: rozpad, nośność, pęcznienie, maksymalny wymiar ziarn, zawartość siarki pirytowej, zawartość węgla. Należy zaznaczyć, że w geologii używa się określenia zawartość pirytu (Py), natomiast w budownictwie komuni- 
kacyjnym używa się określenia zawartość siarki pirytowej (SP). Zależność między tymi parametrami jest wyrażona wzorem:

$$
S P=53,53 \cdot P y / 100
$$

W artykule Gogoli i in. (2012) wskazano na metodę prognozowania zagrożenia pożarowego zwałowisk odpadów powęglowych, opracowaną w 1966 r. Przedstawiono modyfikację metody oceny i klasyfikacji zagrożenia pożarowego na terenach lokowania odpadów powęglowych.

Można przeprowadzić teoretyczną analizę zastosowania tej metody oceny dla warstwy nasypu zbudowanej z kruszywa z łupka powęglowego z pirytem. W takiej analizie istotne staje się uziarnienie, maksymalna wielkość ziarn kruszywa, stan zagęszczenia i kubatura warstwy, czyli parametry kluczowe $\mathrm{w}$ projektowaniu nasypów w metodyce stosowanej w budownictwie drogowym. W tej technologii, ujętej w normie PN-S-02205:1998, przy projektowaniu nasypu uwzględnia się m.in. następujące warunki konstrukcyjne warstwy, które mogą być odniesione również do warstwy z kruszywa z łupka powęglowego z pirytem:

- grubość warstwy,

- wskaźnik zagęszczenia,

- poziom wody gruntowej,

- układ warstw,

- następstwo warstwy pod,

- następstwo warstwy nad,

- szczelność górnej powierzchni nasypu,

- rodzaj kruszywa i zagęszczenie wolnych powierzchni nasypu.

Pełny zakres właściwości użytkowych i identyfikacyjnych oraz warunki wbudowania, których brak w normie PN-S-02205:1998 dla kruszyw z łupka powęglowego z pirytem określają Krajowe Oceny Techniczne. W odniesieniu do tych kruszyw właściwości użytkowe dotyczące uziarnienia i wskaźnika zagęszczenia związanego z technologią ich wbudowania wraz z wyżej określonymi warunkami konstrukcyjnymi stają się zasadniczymi czynnikami w projektowaniu nasypów.

\section{SPOSOBY PRZYSTOSOWANIA SUROWCA Z LUPKA POWEGLOWEGO Z PIRYTEM}

Przy zawartości siarki pirytowej powyżej 1,0\% w łupkach powęglowych podczas produkcji kruszywa zaleca się przeprowadzenie procesu unieszkodliwienia pirytu poprzez:

- doprowadzenie odczynu pH do wartości co najmniej 10,5 - np. przy wykorzystaniu popiołów lotnych, pochodzących ze spalania mieszanek paliwowych o odpowiednim odczynie alkalicznym, lub

- zastosowanie dodatku o dużej zawartości tlenku wapnia, o udziale równoważącym kwas siarkowy z procesu rozkładu pirytu - np. przy wykorzystaniu kruszywa wapiennego, dolomitowego, wapiennych popiołów lotnych, wapna palonego itp.

Odczyn pH kruszywa z łupka powęglowego po procesie unieszkodliwienia pirytu może być alkaliczny.

Przeprowadzony proces unieszkodliwiania pirytu pozwala na zamieszczenie w deklaracji właściwości użytkowych zapisu nie dotyczy (NR).

\section{SPOSOBY BUDOWY NASYPÓW Z KRUSZYWA $Z$ LUPKA POWĘGLOWEGO Z PIRYTEM}

Wprowadzanie do obrotu kruszywa z łupka powęglowego jako wyrobu budowlanego do budowy nasypów drogowych w budownictwie komunikacyjnym umożliwia wspomniana deklaracja zgodności z KOT. Określa ona właściwości użytkowe zasadniczych charakterystyk kruszywa z łupka powęglowego, które identyfikują to kruszywo również pod względem zawartości siarki pirytowej. Jednocześnie definiuje warunki stosowania kruszywa z łupka powęglowego do budowy nasypów w zależności od zawartości pirytu, podjętego sposobu przystosowania pod względem chemicznym na etapie produkcji tego kruszywa lub przewidywanych działań technologicznych przy wbudowaniu w nasyp. Zgodnie z wymaganiami określonymi w KOT kruszywo z łupka powęglowego może być wbudowane:

a) z przeprowadzeniem procesu unieszkodliwienia pirytu, jeśli w deklaracji właściwości użytkowych zawartość pirytu określono - nie dotyczy (NR),

b) bez przeprowadzenia procesu unieszkodliwienia pirytu, jeśli w deklaracji właściwości użytkowych wymieniono określoną właściwość użytkową dotyczącą zawartości pirytu, jak niżej:

- w systemie naprzemiennym z warstwami kruszywa lub gruntu spełniających określone wymagania KOT IBDiM,

- w systemie warstwowym z dodatkowym zabezpieczeniem zewnętrznych powierzchni gotowego nasypu warstwą okrywową zabezpieczającą przed wpływem czynników atmosferycznych i powietrza do wnętrza nasypu o określonej grubości i wykonanej z kruszyw lub gruntów ustalonych w KOT IBDiM.

Kruszywo z łupka powęglowego może być ulepszane (pod względem nośności, uziarnienia i innych właściwości) innymi kruszywami lub spoiwami drogowymi. Należy pamiętać, że składowanie kruszywa z łupka powęglowego przed wbudowaniem w miejscu produkcji i na budowie może prowadzić do zmian granulometrycznych pod wpływem czynników atmosferycznych. Fakt ten należy wziąć pod uwage przed wbudowaniem, a w przypadku rozpadu przeprowadzić ponownie jego klasyfikację ze względu na uziarnienie.

\section{MATERIALY I METODY BADAŃ}

\section{Uziarnienie}

Badania uziarnienia przeprowadzono wg PN-EN 933-1. Kruszywa z łupków powęglowych należą do kruszyw słabych oraz, jak już wspomniano, podlegają zmianom granulometrycznym nawet przed ich wbudowaniem czy podczas zagęszczania. Nie uwzględnienie tych niekorzystnych cech przy doborze ich uziarnienia prowadzi do jego niewłaściwej identyfikacji. W związku z tym próbę po badaniu uziarnienia poddano 5-krotnemu zagęszczeniu metodą Proctora wg PN-EN 13286-2 i ponownie przeprowadzono badanie uziarnienia wg PN-EN 933-1. Powyższy sposób badania jest zgodny z WT-4 2010 dla kruszyw słabych. Badania uziarnienia i uziarnienia po 5-krotnym zagęszcze- 


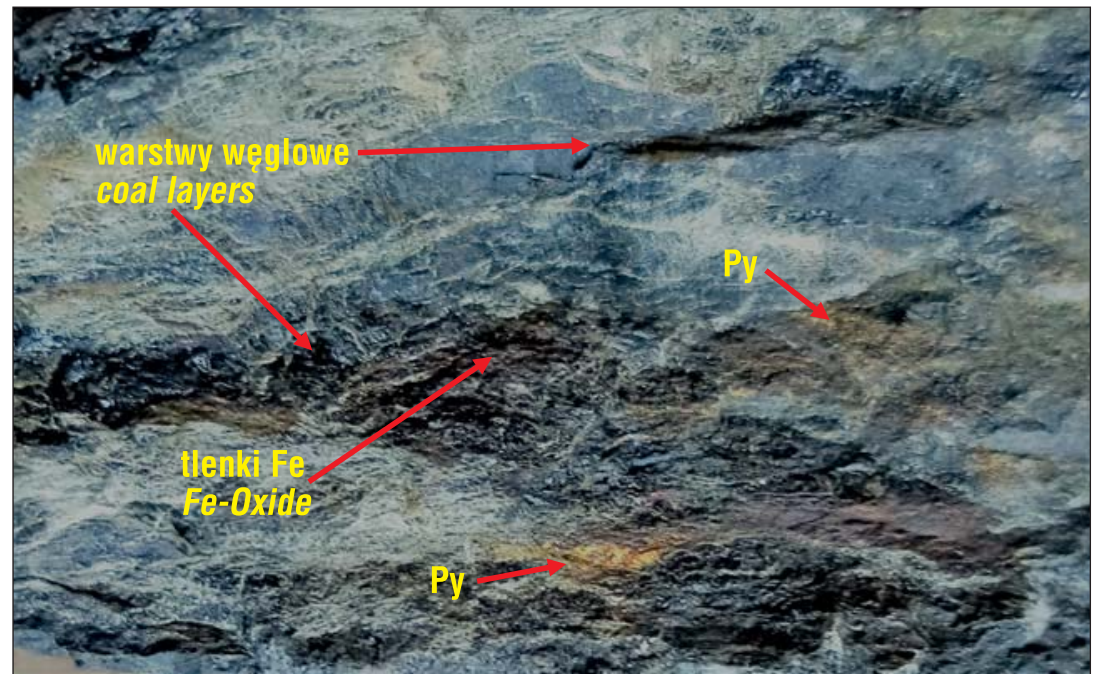

Ryc. 3. Fragment $50 \times 40 \mathrm{~mm}$ przełomu ziarna kruszywa z ziarnami pirytu (Py) i produktami przemiany w postaci tlenków i wodorotlenków żelaza (tlenki $\mathrm{Fe}$ ) w warstwach węglowych w tupku powęglowym

Fig. 3. Part of $50 \times 40 \mathrm{~mm}$ fracture of aggregate grain with pyrite grains (Py) and transformation products in the form of iron oxides and hydroxides (Fe-Oxides) in coal layers of coaly shale

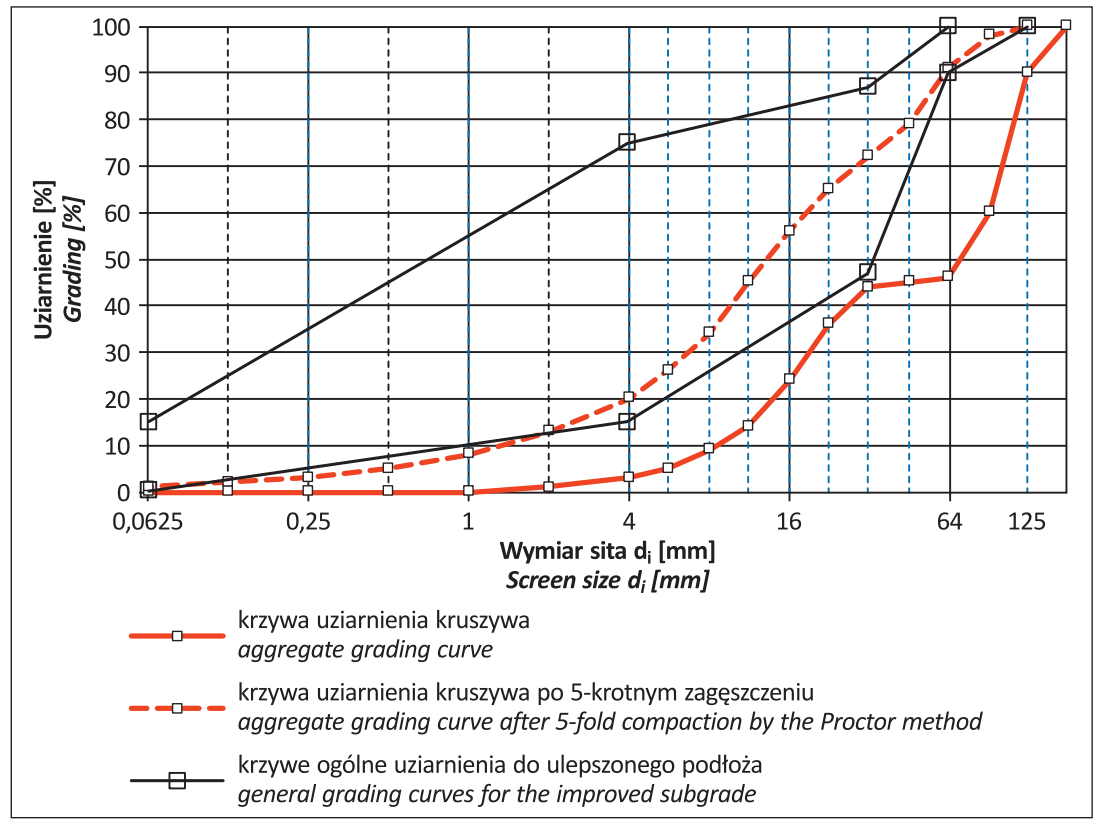

Ryc. 4. Krzywa uziarnienia i krzywa uziarnienia kruszywa z łupków powęglowych po 5-krotnym zagęszczeniu metodą Proctora wg PN-EN 13286-2 w polu dobrego uziarnienia wyznaczonym przez krzywe graniczne uziarnienia dla ulepszonego podłoża wg PN-EN 13285

Fig. 4. Granulation curve and granulation curve of coal shale aggregate after 5-fold densification by the Proctor method acc. to PN-EN 13286-2 in the field of good grain size determined by the grain size limit curves for the improved subsoil acc. to PN-EN 13285

niu metodą Proctora wg PN-EN 13286-2 prowadzono na sucho.

\section{Przełom ziarna kruszywa}

Dla wybranych ziaren kruszywa o wymiarze $63 \mathrm{~mm}$ wykonano ich przełom. Na skadrowanym fragmencie przełomu zaznaczono ziarna kruszywa z ziarnami pirytu (Py) i produktami przemiany w postaci siarczanów żelaza (siar- czany Fe) w warstwach węglowych w łupku powęglowym (ryc. 3).

\section{Szczelność}

Do oceny szczelności wykorzystano badania gęstości objętościowej ziarn $\left(\rho_{s s d}\right)$ wg PN-EN 1097-6 i optymalnej gęstości objętościowej metodą Proctora $\left(\gamma_{o s \max }\right)$ wg PN-EN 13286-2. Szczelność $C$ określano względem gęstości objętościowej ziarn dla optymalnej gęstości objętościowej wg wzoru:

$$
C=\frac{\gamma_{\text {os max }}}{\rho_{\text {ssd }}} \cdot 100
$$

\section{WYNIKI BADAŃ}

\section{Uziarnienie}

W przypadku kruszywa z łupków powęglowych uziarnienie stanowi zasadniczą charakterystykę istotnie związaną z zagęszczeniem i późniejszymi zmianami w wyniku eksploatacji w miejscu zastosowania tego kruszywa. Na rycinie 4 zaprezentowano krzywą uziarnienia i krzywą uziarnienia po 5-krotnym zagęszczeniu metodą Proctora wg PN-EN 13286-2 dla przykładowego kruszywa z łupków powęglowych. Krzywe tych uziarnień przedstawiono w polu dobrego uziarnienia wyznaczonym przez ogólne krzywe graniczne uziarnienia wg WT-4 2010 dla ulepszonego podłoża kategorii uziarnienia $G_{v}$ wg PN-EN 13285 odpowiedniej dla tego typu kruszyw.

W celach poglądowych krzywe uziarnień (ryc. 4) przedstawiono dla pełnego kompletu sit, chociaż wymagany zakres sit dla kruszywa 0/63 przeznaczonego do ulepszonego podłoża powinien obejmować tylko sita $125 ; 63 ; 31,5 ; 4$ i $0,063 \mathrm{~mm}$.

Uwage zwraca przede wszystkim dwufrakcyjny przebieg krzywej uziarnienia kruszywa z łupków powęglowych, która jednak po 5-krotnym zagęszczeniu ulega wygładzeniu. W ostatnim przypadku krzywa uziarnienia mieści się w polu dobrego uziarnienia dla ulepszonego podłoża wg (WT-4, 2010). Maksymalna zmiana uziarnienia pomiędzy uziarnieniem i uziarnieniem po 5-krotnym zagęszczeniu wynosi $41 \%$ na sicie $63 \mathrm{~mm}$. Wynik ten potwierdza, że badane kruszywo jest kruszywem słabym i ulega dużemu rozkruszeniu oraz że nawet 5-krotne zagęszczenie nie prowadzi do powstania zwiększonej zawartości pyłów.

W tym miejscu można przywołać normę PN-S-02205:1998, którą niektórzy projektanci stosują np. 


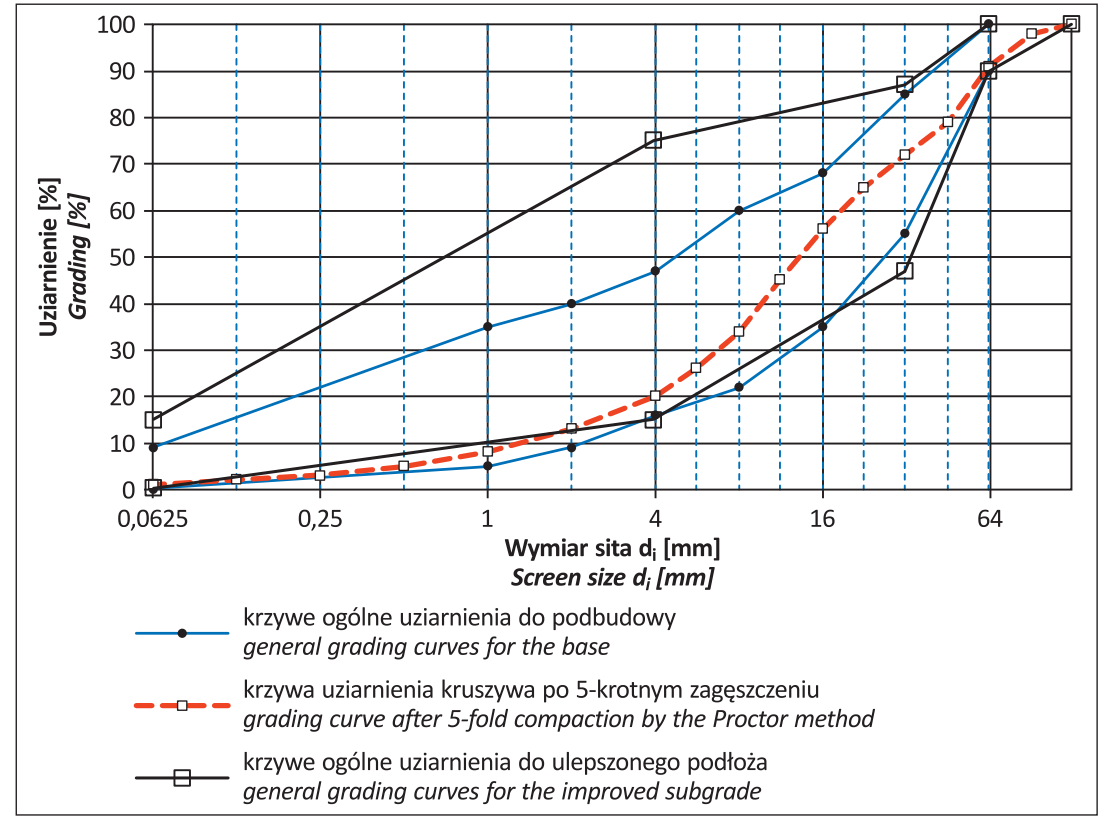

Ryc. 5. Krzywa uziarnienia kruszywa z łupków poweglowych po 5-krotnym zagęszczeniu metodą Proctora wg PN-EN 13286-2 w polu dobrego uziarnienia wyznaczonym przez krzywe graniczne uziarnienia dla ulepszonego podłoża i podbudowy wg PN-EN 13285 according to PN-EN 13286-2 in the field of good grain size determined by the grain size boundary curves for the improved subsoil and base acc. to PN-EN 13285
Fig. 5. Curve of coaly shale aggregate after 5-fold densification by the Proctor method

Na rycinie 5 przedstawiono łącznie pola dobrego uziarnienia $0 / 63$ dla ulepszonego podłoża oraz podbudowy wraz z krzywą uziarnienia kruszywa z łupków powęglowych po 5-krotnym zagęszczeniu metodą Proctora. Pole dobrego uziarnienia dla podbudów mieści się $\mathrm{w}$ polu dobrego uziarnienia dla ulepszonego podłoża. Krzywe uziarnienia mieszczące się w polu dobrego uziarnienia dla podbudów pozwalają na uzyskanie mieszanek o ciągłym uziarnieniu. W przypadku budowanej warstwy w nasypie pozwala na uzyskanie dobrze upakowanych ziaren takiego kruszywa i w konsekwencji ekstremalnej szczelności.

Po drugie spełnienie wymagań związanych z bardzo wąskim polem dobrego uziarnienia dla podbudów jest nieuzasadnione $\mathrm{z}$ uwagi na niejednorodność surowca, jakim jest łupek powęlowy, i nieekonomiczne, ponieważ wymaga dostosowania do wymogów uziarnienia oraz dużego nakładu pracy związanej z rozsiewem na frakcje i mieszaniem w celu uzyskania wymaganej krzywej uziarnienia po 5- krotnym zagęszczeniu.

\section{Gęstość objętościowa ziarn}

doboru uziarnienia kruszyw $\mathrm{z}$ łupka poweglowego do budowy składowisk zdeponowanych odpadów powęglowych. Można wskazać, że obie krzywe (uziarnienia i uziarnienia po 5-krotnym zagęszczeniu) spełniają jej wymagania pod względem uziarnienia, tj. zawartość ziarn poniżej $0,063 \mathrm{~mm}$ jest mniejsza od $15 \%$, a wskaźniki różnoziarnistości są większe od 5. Stosowanie ww. normy nie pozwala na uwzględnienie zmienności składników w kruszywie.

Odmiennym aspektem jest dobór uziarnienia kruszyw $\mathrm{z}$ łupka powęglowego do zastosowania w warstwach powierzchni składowiska zdeponowanych odpadów powęglowych w celu przeciwdziałania samozapaleniom i utlenianiu pirytu. W tym wypadku wymagane sa szczelne mieszanki o uziarnieniu mieszczącym się w polu dobrego uziarnienia dla podbudów drogowych.

Tab. 1. Wyniki badań gęstości i szczelności

Table 1. The test results of density and compactnessity

\section{i optymalna gęstość objętościowa wg metody Proctora}

Wyniki badań gęstości i szczelności zawiera tabela 1 . Szczelność o wartości $80 \%$ jest typowa dla tego rodzaju kruszyw. W celu uzyskania lepszej szczelności można poprawić ciagłość krzywej uziarnienia kruszywa z łupków powęglowych po 5-krotnym zagęszczeniu metodą Proctora wg PN-EN 13286-2 (ryc. 5) poprzez dodanie innego kruszywa frakcji poniżej $8 \mathrm{~mm}$.

\section{PODSUMOWANIE}

Kruszywo z łupka powęglowego speł- niające właściwości użytkowe określone w KOT może być stosowane w budownictwie drogowym przede wszystkim do budowy nasypów. W przypadku identyfikacji surowca z lupka

\begin{tabular}{|c|c|c|c|c|}
\hline $\begin{array}{l}\text { Lp. } \\
\text { No. }\end{array}$ & $\begin{array}{l}\text { Właściwość } \\
\text { Characteristic }\end{array}$ & $\begin{array}{c}\text { Oznaczenie } \\
\text { Identification }\end{array}$ & $\begin{array}{c}\text { Jednostka } \\
\text { Unit }\end{array}$ & $\begin{array}{l}\text { Wynik } \\
\text { Result }\end{array}$ \\
\hline \multirow{4}{*}{1} & $\begin{array}{l}\text { gęstość objętościowa ziarn dla frakcji: } \\
\text { bulk density of grains for the fraction: }\end{array}$ & \multirow{5}{*}{$\rho_{\text {ssd }}$} & \multirow{6}{*}{$\mathrm{Mg} / \mathrm{m}^{3}$} & - \\
\hline & $31,5-63,0 \mathrm{~mm}$ & & & 2,51 \\
\hline & $4,0-31,5 \mathrm{~mm}$ & & & 2,34 \\
\hline & $0,063-4,0 \mathrm{~mm}$ & & & 2,33 \\
\hline 2 & $\begin{array}{l}\text { gęstość objętościowa ziarn kruszywa } \\
\text { bulk density of aggregate grains }\end{array}$ & & & 2,37 \\
\hline 3 & $\begin{array}{l}\text { optymalna gęstość objętościowa } \\
\text { metodą Proctora } \\
\text { optimal bulk density by Proctor } \\
\text { method }\end{array}$ & $\gamma_{\text {os max }}$ & & 1,88 \\
\hline 4 & $\begin{array}{l}\text { szczelność } \\
\text { compactnessity }\end{array}$ & $\mathrm{C}$ & $\%$ & 80 \\
\hline
\end{tabular}


powęglowego o zawartości siarki pirytowej powyżej 1,0\%, zaleca się: lub

- przeprowadzenie procesu unieszkodliwienia pirytu,

- wbudowanie w systemie warstwowym $\mathrm{z}$ dodatkowym zabezpieczeniem zewnętrznych powierzchni gotowego nasypu z warstwą okrywową.

Warstwa okrywowa wykonana z kruszyw lub gruntów ustalonych w KOT IBDiM i o określonej grubości zabezpiecza wnętrze nasypu przed wpływem czynników atmosferycznych i dostępem powietrza z zewnątrz. Wskazano przy tym, na prawidłowy pod względem szczelności dobór uziarnienia tych kruszyw do wbudowania w nasypy.

Wybór sposobu wbudowania takich kruszyw zależy od surowca, jakim jest łupek powęglowy z pirytem, ale również od doświadczenia uczestników projektowania i budowy w zakresie budownictwa drogowego.

Autorzy bardzo serdecznie dziękują recenzentom: dr. hab. inż. Wojciechowi Bańkowskiemu oraz dr. hab. inż. Henrykowi Woźniakowi, za wnikliwe recenzje i cenne uwagi oraz całej Redakcji Przeglądu Geologicznego.

\section{LITERATURA}

BLASCHKE W., BAIC I., SOBKO W., BIEL K. 2018 - Usuwanie siark Z węgla kamiennego z wykorzystaniem wibracyjno-powietrznego separatora typu FGX. Czasopismo Techniczne KTT, 138: 176-177. BOCHENEK D. (red.) 2017 - Ochrona Środowiska 2017. Informacje i opracowania statystyczne. GUS, Warszawa.

DUSZYŃSKI A., JASIŃSKI W., PRYGA-SZULC A. 2018 - Kruszywa $z$ łupka poweglowego - charakterystyka i zastosowanie. Biul. Państw. Inst. Geol., 472: 321-325.

GOGOLA K., BAJERSKI A., SMOLIŃSKI A. 2012 - Modyfikacja metody oceny zagrożenia pożarowego na terenach lokowania odpadów powęglowych. Pr. Nauk. GIG, Górnictwo i Srodowisko, 2: 13-32. http://geoportal.pgi.gov.pl/odpady/wytwarzanie/prognozy,

KLOJZY-KARCZMARCZYK B., MAZUREK J., PAW K. 2016 Możliwości zagospodarowania kruszyw i odpadów wydobywczych górnictwa węgla kamiennego ZG Janina w procesach rekultywacji wyrobisk odkrywkowych. Gosp. Sur. Miner., 32 (3): 111-134

KOZIOŁ W., CIEPLIŃSKI A., MACHNIAK Ł., BORCZ A. 2015 - Kruszywa w budownictwie. Cz. 2. Kruszywa alternatywne. Now. Bud. Inż., 5: $35-40$.

MACHNIAK Ł., KOZIOŁ W. 2014 - Kruszywa alternatywne - baza zasobowa i kierunki wykorzystania w budownictwie. Kruszywa: produkcja - transport - zastosowanie, 4: 28-33.

MIKLIS P. 2019 - Zabezpieczenie i zagospodarowanie zwałowisk pogórniczych. Informacja o wynikach kontroli. Delegatura w Katowicach, Nr. ewid. 158/2018/P/18/067/LKA, NIK, Warszawa.

PN-EN 933-1 Badania geometrycznych właściwości kruszyw - Część 1: Oznaczanie składu ziarnowego - Metoda przesiewania.

PN-EN 1097-6 Badania mechanicznych i fizycznych właściwości kruszyw - Część 6: Oznaczanie gęstości ziarn i nasiąkliwości.

PN-EN 13286-2 Mieszanki niezwiązane i związane hydraulicznie - Część 2: Metody badań laboratoryjnych gęstości na sucho i zawartości wody - Zagęszczanie metodą Proctora.

PN-S-02205:1998 Drogi samochodowe - Roboty ziemne - Wymagania i badania.

PN-EN 13285 Mieszanki niezwiązane - Specyfikacja.

ROZPORZĄDZENIE Rady Ministrów z dnia 22 grudnia 2017 r. w sprawie jednostkowych stawek opłat za korzystanie ze środowiska. Dz.U. z 2017 r. poz. 2490.

SOKÓŁ W., TABOR A. 1996 - Problemy zagospodarowania odpadów powęglowych z górnictwa węgla kamiennego w Polsce. Prz. Geol., 44 (7): 710-715.

SZPADT R. 2010 - Prognoza zmian w zakresie gospodarki odpadami. Sfinansowano ze środków NFOŚiGWna zamówienie Ministra Środowiska. Kamieniec Wrocławski.

WT-4, 2010 - Mieszanki niezwiązane do dróg krajowych. Wymagania techniczne. Załącznik Nr 3 do Zarządzenia Nr 102 Generalnego Dyrektora Dróg Krajowych i Autostrad z dnia 19 listopada 2010 r.

Praca wpłynęła do redakcji 25.06.2020 r.

Akceptowano do druku 7.08.2020 r. 